\title{
WINTER ECOLOGY OF HARRIERS ROOSTING AT AKOLA, MAHARASHTRA, INDIA
}

\author{
Ashok Verma
}

Sarafa Bazar, Rekha Naanga Street, Bharatpur, Rajasthan 321001, India

Present address: Wildlife Institute of India, Post Box 18, Chandrabani, Dehradun, 248 001, India

E-mail:vermaasok@rediffmail.com

\begin{abstract}
A study was undertaken on wintering ecology of harriers during February 2003 and October 2004 at Akola district of Maharashtra, western India. The data collected from a communally roosting harriers estimated a maximum population at roost was ca. 200 and 72 harriers during February 2003 and October 2004, respectively. Four species of harriers roosted namely Eurasian Marsh, Montagu's, Pallid and Hen harriers. Montagu's harriers dominated the roost. In all, 105 pellets were collected from the roost to obtain information on diet composition of wintering harriers at Akola. More than $80 \%$ pellets contained locust remains. Other prey items consumed by harriers included reptiles (lizards, skinks and snakes), birds (small land birds) and small mammals (rodents). The diet was compared with other harriers' roosting elsewhere in India and Africa. The paper also describes roost habitat and roosting behaviour. Major threats of roosting harriers are highlighted.
\end{abstract}

\section{KEYWORDS}

Akola district, communal roosting, diet composition, Eurasian Marsh Harrier, Hen Harrier, Montagu's Harrier, Pallid Harrier, roost habitat, roosting behaviour

Harriers are long distance migrants to India. They are diurnal raptors, which have adapted to a life style in open grassland and wetland. They generally arrive in India by end of July and are seen until April and are probably the first among migratory raptors to arrive in India. However, a few juveniles are sighted until June (Verma, 2002b).

The greatest diversity of harriers is reported from India postbreeding (Simmons, 2000). Of 16 harrier species all over the world, six winter in India every year, i.e. Montagu's Circus pygargus, Pallid $C$. macrourus, Hen $C$. cyaneus, Pied $C$. melanoleucos, Eurasian Marsh $C$. aeruginosus and Eastern Marsh C. spilonotus harriers. Montagu's, Marsh and Pallid harriers are widely distributed in India while Pied and Eastern Marsh harriers are confined to the eastern parts of India, and Hen harriers are commonly seen in northern India east to Upper Assam (Ali \& Ripley, 1983). Except for Pied Harrier there is no confirmed record of any other harrier breeding in India (Narayan \& Rosalind, 1991). A harrier ringed at Bharatpur $\left(27^{\circ} \mathrm{N} \& 77^{\circ} \mathrm{E}\right)$, (Ali \& Ripley, 1983) on 25 March 1962, which was recovered about $4000 \mathrm{~km}$ far away in Kazhaksthan $\left(53^{\circ} \mathrm{N} \& 66^{\circ} \mathrm{E}\right)$ after three years on 7 May 1965 (Igor Fefelov, pers. comm.) suggests that part of harrier population wintering in India come from Asian breeding grounds. However, further studies are required to investigate the origin of harriers in India.

Outside the breeding season, harriers tend to base themselves in communal roost-sites, from which they spread out to hunting areas during the day (Newton, 1979). They are known to use the same roost-sites regularly for years, if undisturbed (Verma, 2002b). BirdLife International - an international conservation body has recommended roost counts for globally threatened Pallid Harriers (International Action Plan for the Pallid Harrier, 2003) for monitoring of their population trends (BirdLife International, 2003). These sites also act as easy source for collecting large information on their winter diet from pellets which are egested at such sites by roosting harriers.

Various communal roosts exist in India. They are (1) Velavadar National Park, Gujarat (Clarke et al., 1998) - the world's largest known roost, (2) Rollapadu Wildlife Sanctuary (Rahmani \& Manakadan, 1987), (3) Alwal grassland (Ganesh \& Kanniah, 2000) in Andhra Pradesh, (4) Banni grasslands of Kutch, Gujarat (Samant et al., 1995), (5) Keoladeo National Park at Bharatpur in Rajasthan (Samant et al., 1995; Verma, 2002a), (6) Grasslands at Mumbai (pers. obs.), and (7) Akola grassland, Akola district in Maharashtra (pers. obs.).

The present paper reveals various aspects of winter ecology of harriers, primarily population, diet, roost, habitat-use and behaviour. The diet is compared with harriers roosting at other similar roosts from within (Clarke, 1996) and outside the country (Cormier \& Baillon, 1991).

\section{Study Area}

The study area was located at Akola city $\left(20^{\circ} 43^{\prime} \mathrm{N} \& 7^{\circ} 04^{\prime} \mathrm{E}\right.$; $308 \mathrm{~m}$ ) in Akola district, northern Maharashtra in western India which experiences arid to semi arid climate.

The roost site was about $14 \mathrm{~km}$ from the city railway junction near Washimba village's barren fields. It is around $5 \mathrm{~km}^{2}$ of total grassland-dominated area important for harrier conservation. Except for a small patch of grassland belonging to the forest reserve most of the area is revenue and private land.

The district as a whole is a prosperous Cotton Gossypium and Jowar Sorghum (called kharif crop grown in June to October) farming zone - an area typical for harriers as reported from elsewhere in the country. The forest type is South Indian Tropical dry deciduous. The area records average annual rainfall of $846.5 \mathrm{~mm}$ and the temperature between $2-42^{\circ} \mathrm{C}$.

The vegetation was dry deciduous type comprising Acacia catechu, Acacia nilotica, Butea monosperma, Ziziphus mauritiana, Prosopis spicigera and Acacia leucophloea. The roost-site had various grasses, herbs, shrubs and a few trees.

(C) Zoo Outreach Organisation; www.zoosprint.org Manuscript 1350; Received 12 April 2005; Revised received 18 May 2005; Finally accepted 21 June 2005; Date of publication 21 July 2005 


\section{Methodology}

The study took place on 16-17 February 2003 and 19-22 October 2004. The roosting population was estimated, by counting harriers arriving to the roost in flight, by a team of two persons from vantage points. The observations were started about two hours before sunset and lasted for one hour after sunset. Harriers arriving early to the roost spend substantial amount of time on pre-roosting before settling for permanent roosting (Verma, 2002b).

The count was repeated in the following morning about two hours before sunrise and continued until all birds had flown from the roost. Except for a few harriers, generally all birds leave the area to their respective foraging grounds.

After their departure from the roost, the area was surveyed intensively for pellets and to gather information on roost habitat use. Vegetation composition, their height, space occupancy by roosting harrier, and the extent of roost habitat were estimated (considering pre-roosting perches as boundary).

The actual roost sites of harriers were identified by the presence of excreta, downy feathers and pellets. Collected pellets were dissected dry by crushing them and undigested parts of various prey species devoured by harriers were separated out and classified into various prey classes such as insect, reptile, bird and mammal (rodents). The various prey remains segregated were bones, feathers, fur, scales, teeth, and chitinous parts of insects. The species level identification of prey species was restricted to a few species.

\section{Results}

\section{Species composition and roosting population}

In all, four species of harriers roosted at Akola grassland. They were $C$. aeruginosus, C.pygargus, $C$. macrourus and $C$. cyaneus harriers. During February 2003, the species roosting were $C$. macrourus, C. cyaneus, and C. pygargus while in October 2004 $C$. cyaneus could not be sighted, instead $C$. aeruginosus was observed. About 75 harriers in October 2004 and 200 harriers in February 2003 were recorded roosting here.

Although all birds could not be identified to species level, during the month of February, 25 harriers sexed randomly showed $C$. pygargus to be the dominant species $(76 \%)$ followed by $C$. macrourus $(16 \%)$ and $C$. cyaneus $(8 \%)$; whereas in the month of October C. pygargus accounted for $68 \%$, C. macrourus $14 \%$ and $C$. aeruginosus $18 \%$.

The roosting population was represented both by adults and juveniles. For $C$. cyaneus only males were sighted. An attempt was made to assess the age and sex class of the roosting harriers during October and it showed that males dominated the population followed by juveniles and females (Table 1).

\section{Roosting behaviour}

The harriers before going for permanent roosting spent considerable time pre-roosting, sitting close to the roost-site. The behaviour was categorized as pre-roosting, roosting and
Table 1. Population structure of roosting harriers recorded on 19 October 2004 at Akola grasslands.

\begin{tabular}{llll}
\hline Species & Adult male & Adult female & Juvenile \\
\hline C. pygargus $(\mathrm{n}=49)$ & $31 \%$ & $32 \%$ & $37 \%$ \\
C. aeruginosus $(\mathrm{n}=13)$ & $46 \%$ & $23 \%$ & $31 \%$ \\
C. macrourus $(\mathrm{n}=10)$ & $40 \%$ & $30 \%$ & $30 \%$ \\
\hline
\end{tabular}

post-roosting.

During my two visits in February 2003 and October 2004, I found harriers arriving at the roost-site about 1-2 hours before roosting and they perched on the ground in the grasses in and around the roost-site. However, many settled away from the roost area pre-roosting on the ground with a few on trees $(n=$ 5). During this period, they rested quietly and preened mostly. They got off the ground and inspected the area a few times. The new arrivals, generally after having searched the roostsite, joined the sitting harriers indulging themselves in the same activities. The most important activity noted at pre-roosting was vocalization. Probably the dominant birds, mostly adult females, vocalized at the arriving harriers to the roost which lasted until the intruder had flown away from its roosting territory. However, all the sitting harriers did not attempt vocalization. Males were mostly silent.

Just at the sunset, the harriers became more active. They left their pre-roost perches one after another and started circling low over the roost-site followed by many settlings and resettlings into the vegetation. This was, perhaps, the final preparation and selection of actual roost-sites where they would spend the night. They trampled the vegetation so as to form a hollow structure of soft roosting platform. The activity lasted for about half an hour. It was a spectacular phenomenon as sometimes all the pre-roosting harriers and the ones still arriving to the area would circle all together over the site and the adjacent areas. At times, they formed several small groups and inspected the area for presence of mammalian and avian predators. During this activity vocalization was also heard many times. They only started roosting after they were confirmed of no danger in the roosting area. Though there could not be direct sightings of any predators, scats found the next day during pellet collection confirmed the presence of mammalian predators in the roost-site. Dusky Eagle Owl Bubo coromandus was also sighted in the area, which could be another potential predator for harriers.

Most of the harriers departed early in the morning about half an hour before sunrise in very dim light and very few left after sunrise. In February 2003, of the 200 harriers almost all except two flew off the roost site. The two remaining harriers after about half an hour of resting and preening resumed foraging in and around the roost site. The post roosting flight of harriers was direct, fast and purposeful, probably directed towards their foraging grounds. They spread in all directions but mostly heading towards North. Some harriers before finally heading towards their foraging sites circled twice or thrice over the roost-site, rested for 5 to 15 minutes close to the roost site and again circled over the roost site. They departed in ones, twos 
and threes. However, it was generally a party of two-three birds leaving the roost. On three occasions antagonistic behaviour was observed between Montagu's Harrier and Pallid Harrier when the former vocalized and attacked the latter. The two harriers at post roost, after about half an hour's resting and preening, resumed foraging in and around the roost site.

\section{Roost-habitat}

Macro habitat: All the harrier species roosted in a wide-open grassland patch devoid of trees. However a few trees $(n=3)$ were present bordering the roost. Only $25-30 \%$ of the area of about $1 \mathrm{~km}^{2}$ was used for actual roosting. It was grassdominated area interspersed with herbs and shrubs and with few trees mostly bordering the roost-site. Cotton-dominated crops surrounded the roost by three sides and the remaining side is a scrub land and a valley.

Micro-habitat: The height of the grassland providing cover to the roosting harriers ranged between $1-2.5 \mathrm{~m}$. The dominant grass species forming roost habitat were Ischaemum rugosum, Themeda quadravalvis, Sehima notatum, Aristida funiculata, Heteropogon contortus, Lophopogon tridentatus, Chrysopogon fulvus, Dichanthium annulatum and Panicum deccanense. Other vegetations included Brachiaria deflexa, Tragus roxburghii, Oplismenus burmanii, Cenchrus setigerus, C. paludosum and Metanocenchris jacquemontii.

Woody species like Acacia catechu, Prosopis spicigera, Z. mauritiana and A. nilotica were also present in the roost-site. Of the four grassland patches used by harriers for roosting it was found that they selected treeless grass patches more. In one instance a maximum of 200 harriers alighted in an all open grassland patch to roost.

The harriers roosted in several small groups evidenced by presence of pellets in clusters. The distance from one group to another ranged between $1-4 \mathrm{~m}$. Each harrier had a separate site of about $1 \mathrm{~m}^{2}$ surrounded by standing vegetation on all sides, keeping a distance of about $1 \mathrm{~m}$ from each other. They were well hidden in the tall grasses and were visible only from a distance as close as $1 \mathrm{~m}$ of the actual rooting site. The harriers roosted mostly on grasses trampled either by themselves or by ungulates.

There were a few sites where harriers roosted more than once. These were in fact the resting sites of ungulates like, Blackbuck Antilope cervicapra, Nilgai Boselaphus tragocamelus and feral cows Bos indicus, confirmed by their pellets and dung at the roost. At such another site a maximum of 10 pellets were collected, including old and fresh, suggesting a roosting territory of a harrier. However, more studies are needed to confirm whether they hold roost territories or keep shifting day after day.

\section{Predators}

The potential predators at the roosting area were Jungle Cat Felis chaus, Jackal Canis aureus, and Striped Hyena Hyaena hyaena and Dusky Eagle Owl. The scats collected of Jungle
Cat ( 2 scats) and Hyaena (1 scat) confirmed their presence in the area. While collecting pellets, I collected two dead harriers completely eaten except for wings.

\section{Winter diet of harriers}

The harriers congregated at the roost were from c. $20 \mathrm{~km}$ radius around the roost. A study conducted in Keoladeo National Park, Rajasthan on radio tagged Marsh Harriers found them traveling a distance between 3-12km (Verma, 2002b) while in another study on radio tagged Marsh and Montagu's harriers at Velavadar National Park, Gujarat it was $20 \mathrm{~km}$ (pers. obs.).

The diet was analyzed using fresh pellets collected from the roost. Of 105 pellets, 58 intact pellets were considered to for pellet morphometry, i.e., pellet shape, size and number of grasshoppers per pellet (by counting the number of mandibles). Pellets were $3.7 \pm 0.96 \mathrm{~cm}$ long and $1.5 \pm 0.24 \mathrm{~cm}$ wide. The number of mandibles ranged between 7 to 76 per pellet. However, in 28 intact pellets of only grasshoppers, the number of mandibles counted were between 9-76 indicating 5 to 38 grasshoppers eaten by the harrier to form one pellet.

The various shapes recorded for pellets were conical, spherical, bean shaped, cylindrical, and oval. Maximum number of pellets were cylindrical in shape, consisting wholly or predominantly of grasshopper.

The wintering harriers at Akola consumed wide spectrum of prey items, which included insects, reptiles, birds and small mammals. Locusts (Family Acrididae) formed the major insectivorous diet. Nomadacris succincta (or Bombay Locust) constituted the major part of the winter diet. Common garden lizard (Calotes versicolor), snakes and skinks formed reptilian diet of harriers at Akola. Ten prey classes were identified for wintering harriers from the pellets (Table 2). There were $58 \%$ pellets which consisted only locust, $6 \%$ only bird, $5 \%$ only mammal and $1 \%$ only reptile. Remaining pellets had more than one prey class in them, for example, locust and mammal (12\%), and, locust and reptile (11\%) (Table 2). However overall 84\% pellets contained locust remains in them.

There were 73 pellets, which had only one prey class in them, and remaining had two $(n=29)$ and three prey classes $(n=3)$. A significant difference was noted in the prey classes in both the roost sites at Akola and Gujarat $\left(\mathrm{c}^{2}{ }_{15}=372, \mathrm{p}<0.01\right)$ within the country. A significant difference was observed in the consumption of locusts among all three sites $\left(\mathrm{c}^{2}{ }_{2}=7.4, \mathrm{p}<0.05\right)$. $58 \%$ of pellets had only locusts as diet at Akola whereas at VNP $40 \%$ pellets had only locusts while at Senegal roost in Africa $74 \%$ pellets had only locusts as winter diet (Table 2).

\section{Discussion}

The communal roost of harriers at Akola grasslands lies over $500 \mathrm{~km}$ towards east of the Blackbuck National Park, Velavadar in Gujarat, NW India which holds the largest roost of wintering harriers in the world (c 3000 harriers, Clarke et al., 1998). It is likely that harriers arriving to Velavadar move down to Akola and further southwards. However, another roost c. $1000 \mathrm{~km}$ 
Table 2. Diet composition of harriers at Akola, Maharashtra (India) during 2003

\begin{tabular}{lllllll}
\hline Prey category & \multicolumn{2}{l}{$\begin{array}{l}\text { Maharashtra } \\
\text { (Akola) }\end{array}$} & \multicolumn{2}{l}{$\begin{array}{l}\text { Gujarat } \\
\text { (Velavadar) }\end{array}$} & \multicolumn{2}{l}{$\begin{array}{l}\text { Africa } \\
\text { (Senegal) }\end{array}$} \\
& N & $\%$ & N & $\%$ & N & $\%$ \\
\hline Locust only & 61 & 58 & 54 & 40 & 84 & 74 \\
Locust, bird & - & & 6 & 4 & 3 & 3 \\
Locust, mammal & 13 & 12 & 8 & 6 & 21 & 18 \\
Locust, reptile & 12 & 11 & 9 & 7 & 2 & 2 \\
Locust, bird, reptile & - & & 3 & 2 & & \\
Locust, mammal, reptile & 2 & 2 & 1 & 1 & & \\
Locust, bird, mammal & 1 & 1 & - & & & \\
Absence of locusts & & & & & 3 & 3 \\
Bird only & 6 & 6 & 32 & 24 & & \\
Bird, mammal & - & & 3 & 2 & & \\
Bird, reptile & 1 & 1 & 6 & 4 & & \\
Bird, mammal, reptile & - & & 2 & 2 & & \\
Mammal only & 5 & 5 & 8 & 6 & & \\
Mammal, reptile & 3 & 3 & 2 & 2 & & \\
Reptile only & 1 & 1 & - & & & \\
Total & 105 & & $\mathbf{1 3 4}$ & & & \\
\hline
\end{tabular}

$\mathrm{N}$ - pellets

away to its north is located in Keoladeo National Park, Rajasthan holding about 150 harriers. Probably, a large number of harriers arriving in India use the Indus migratory flyway. Detailed study is required to understand harrier movement pattern in northwestern India. The recurring nature of roosts in winter quarters provide excellent opportunity for long term monitoring of population trends in harriers.

At Akola, the presence of a high number of males and juveniles indicate that the water bodies located at a distance of a kilometere from the present roost (teeming with resident waterfowls and other aquatic long-legged birds) could attract Marsh and Hen harriers in early and mid winter both for foraging and roosting.

\section{Significance of communal roosting}

Selection of roost-site becomes critical for survival of harriers in their winter quarters where they are more prone to ground predators like Jungle Cat, Jackal and Python. It has been noted that harriers successfully defend their ground nests from predators with each other's help while nesting in colonies (Simmons et al., 1987; Arroyo et al., 2001) than while breeding individually. Communal defense from predators probably is the reason for forming communal roost. Anti-predatory function of communal roosting in harriers has been supported by BakerGabb (1982), Simmons (2000) and Arroyo (2001). Similar observations were made by Verma (2002b) on Marsh Harriers Circus aeruginosus at Keoladeo National Park, India both at roosting and foraging grounds. However, Ward and Zahavi (1973) suggest communal roosting as center for exchanging information on food resources whereas Wynne-Edwards (1962) finds it useful in bringing members of the population unit together and stimulating adjustment of population density through emigration when pressures are sufficiently high.

\section{Roosting habitat}

Roosts are generally found far from foraging grounds in vast open grounds among tall vegetation of which a small portion is selected for roosting. The tall grassland of Akola was helpful for harrier survival in three ways. First, it provided shelter from cold winter. Substantial mortality has been reported at nocturnal roosts during periods of intense cold stress (Odum \& Pitelka, 1939). At roost sites, average wind velocity reduces by $72 \%$ in comparison to unsheltered locations in wintering Turdus migratorius (Walsber \& King, 1980). Second, they get concealment from predators, and third, their selection of a small portion out of large open patch helps in misguiding their predators about their locations in the vegetation. Also, the rustling sound of the tall grass by the predator movement seems to be helpful in making harriers alert of the danger due to their acute auditory abilities like owls (Rice, 1982). The grassland at Akola with height between $1-2.5 \mathrm{~m}$ provided ideal conditions for harriers to roost. Taller vegetation may act as barrier for avian predators (Hamerstrom \& Kopeny, 1981) like owls which are reported to hunt harriers and kestrels elsewhere (Weller et al., 1955; Newton, 1979).

\section{Winter diet}

C. pygargus dominated the Akola roost. Locusts are reported to be a major diet of Montagu's Harrier from other roosts like Velavadar National Park and Senegal. Locusts dominate the diet of roosting harriers of Akola, which further suggests it to be a $C$. pygargus dominated roost. $C$. pygargus by virtue of being specialist on locusts play an important role in pest control.

Various prey classes recorded in the pellets is due to other harriers roosting here. C. macrourus is known to take more birds other than rodents, reptiles and insects (Cramp \& Simmons, 1980). The roost at Senegal, West Africa (Cormier \& Baillon, 1991) was entirely of $C$. pygargus and hence depicting $74 \%$ pellets with only locust remains whereas in case of Akola and VNP they were mixed roosts. No pellets with waterfowl feathers were found indicating waterfowl dependent harrier species like $C$. aeruginosus and $C$. cyaneus arrived in very low numbers or roosted elsewhere. Most of the waterbodies dry up by February and hence waterfowl dependent $C$. aeruginosus also decline, whereas cotton and jowar dominated crops and dry climate of the area provides an optimal habitat for breeding of grasshoppers - a staple diet of $C$. pygargus.

\section{RECOMmendations}

1. Burning of grasslands including roosting habitat of harriers is a regular practice of Parthis, a tribal community for hunting game birds and mammals. This should be controlled as it affects the roosting harriers which, by compulsion, leave the area due to complete habitat loss.

2. Cattle grazing in the roost-site was confirmed by presence of dungs. It has been found in another roost of harriers at Bharatpur (Verma, 2002b) that grazing directly affects roost population and harriers shift their area to suboptimal habitats.

3. Grass harvesting by locals in the roosting area is also a serious threat for harrier survival. During disturbance harriers shift from one grassland patch to another. Since most of the 
grassland comes under Revenue and Private land Property there is hardly any one to take care of wildlife in the area.

4. Though at present, pesticide-use in the crop fields (mainly cotton) is minimal around roosts where harriers forage, regular monitoring to assess impact of pesticides is required which can affect their breeding success. Since harriers go for long distance foraging they are more prone to pesticide contamination. Hence, monitoring of pesticide use in a radius of $30 \mathrm{~km}$ from the roost is recommended.

5. A canal that is under plan for construction in the near future in the area would attract more villagers and further worsen the situation for harriers.

6. Nature Education Centre (NEC) - The area should be protected legally by declaring the whole area as Reserve Rorest / Community Forest. This can act as Nature Education Centre for creating awareness among public especially children about the importance of wildlife. There is a large water body close to the roost site which attracts a myriad of migratory and nonmigratory birds. Besides this, many mammals are found here, namely, Black Buck, Nilgai, Indian Black-naped Hare, Wild Boar, Jackal, Jungle Cat and Hyaena. Hence, the site also holds potential for eco-tourism.

7. Being at the top of the food chain harriers are reliable indicators of health of the plains. Hence, a long-term monitoring of the roosting harriers should be taken up and efforts to locate satellite-roosts around this site be made as during disturbances to the major roost site the satellite roosts will play a crucial role in species survival.

\section{REFERENCES}

Ali, S. and S.D. Ripley (1983). Handbook of the Birds of India and Pakistan Compact Edition. Oxford University Press, New Delhi. Arroyo, B.E., F. Mougeot and V. Bretagnolle (2001). Colonial breeding and nest defence in Montagu's Harrier (Circus pygargus). Behavioural Ecology and Sociobiology 50: 109-115.

Baker-Gabb, D.J. (1982). Comparative ecology and behaviour of Swamp Harriers Circus approximans and Spotted Harriers $C$. assimilis and other raptors in Australia and New Zealand. D.Phil. Thesis, Monash Univerisity, Victoria. (Unpublished).

BirdLife International (2003). International Action Plan for the Pallid harrier (Circus macrourus). Document prepared by BirdLife International on behalf of the European Commission. Strasbourg, 1-4 December 2003.

Clarke, R. (1996). Preliminary observations on the importance of a large communal roost of wintering harriers in Gujarat (NW India) and, comparison with a roost in Senegal (W. Africa). Journal of the Bombay Natural History Society 93: 44-50.

Clarke, R.,V. Prakash, W.S. Clark, N. Ramesh and D. Scott (1998). World record count of roosting harriers Circus in Blackbuck National Park, Velavadar, Gujarat, north-west India. Forktail 14: 70-71.

Cormier, J.P. and F. Baillon (1991). Concentration de Busards Centrés Circus pygargus (L.) dans la region de $\mathrm{M}$ bour (Sénégal) Durant å hiver 1998-89. Alauda 59: 163-168.

Cramp, S. and K.E.L. Simmons (1980). Handbook of the birds of Europe, the Middle East and North Africa. The birds of western Palearctic Vol. 2. Oxford University Press, London.

Ganesh, T. and P. Kanniah (2000). Roost counts of harriers Circus spanning seven winters in Andhra Pradesh, India. Forktail 16: 1-3.
Hamerstrom, F. and M. Kopeny (1981). Harrier nest-site vegetation. Journal of Raptor Research 15(3): 86-88.

Narayan, G. and L. Rosalind (1991). New record of the Pied Harrier, Circus melanoleucos (Pennant) breeding in Assam Duars, with a brief review of its distribution. Journal of the Bombay Natural History Society 88(1): 30-34.

Newton, I. (1979). Population Ecology of Raptors. Buteo Books, Inc. Vermillion, S.D., 399pp.

Odum, E.P. and F.A. Pitelka (1939). Storm mortality in a winter starling roost. Auk 45: 451.

Rahmani, A.R. and R. Manakadan (1987). A large roost of harriers in Andhra Pradesh. Journal of the Bombay Natural History Society 83 (Supplement): 203

Rice, W.R. (1982). Acoustical location by the Marsh Hawk: adaptation to concealed prey. Auk 99: 403-413.

Samant, J.S., V. Prakash and R. Naoroji (1995). Ecology and Behaviour of Resident Raptors with special Reference to Endangered Species. Final Report (1990-93). Bombay Natural History Society.

Simmons, R.E., P. Barnard and P. Smith (1987). Reproductive behaviour of Circus cyaneus in North America and Europe: a comparison. Ornis Scandinavica 18: 33-41.

Simmons R.E. (2000). Harriers of the World: Their Behaviour and Ecology. Oxford Ornithology Series. Edited by C.M. Perrins, Oxford.

Walsberg, G.E. and J.R. King (1980). The thermoregulatory significance of the nocturnal roost sites selected by robins (Turdus migratorius) wintering in eastern Washington. Wilson Bulletin 91: 3339.

Verma, A. (2002a). A large roost of Eurasian Marsh Harriers Circus aeruginosus at Keoladeo National Park, Bharatpur, India. Forktail 18: $150-151$

Verma, A. (2002b). Wintering ecology of Marsh Harrier. Ph.D. Thesis submitted to Mumbai University, Mumbai. (Unpblished).

Ward, P. and A. Zahavi (1973). The importance of certain asssemblages as "information centres" for food finding. Ibis 115: 517-534.

Weller, M.W., I.C. Adams and B.J. Rose (1955). Winter roosts of Marsh Hawks and Short-eared Owls in Central Missouri. The Wilson Bulletin 67(3): 189-193.

Wynne-Edwards, V.C. (1962). Animal dispersion in relation to social behaviour. London, Oliver and Boyd, 297-299pp.

\section{ACKNOWLEDGEMENT}

My sincere thanks are due to Drs. Jayant Deshmukh, Ajit Deshmukh and Deepak Bhat for kindly supporting my Harrier Roost-site Location Survey at Akola, Maharashtra. I thank Dr. Sehdeo Rothe, Botanist for help in identifying grass species at the harrier roost-site. I also thank Viju, Namdeoji and Dhondu for helping me in the field.

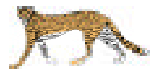

